\title{
OPENING ADDRESS
}

Mr. ELDON GRIFFITHS, M.P.

Government Minister with special responsibility for sport

Department of the Environment, 2 Marsham St., London, SW1P $3 E B$

Mr. President, Mr. Chairman, Your Highness, my Lord Mayor, my Lords, Ladies and Gentlemen.

The talks and the discussions which are to take place during this Congress inevitably and rightly will do so against the background of a World wide explosion in sport. I welcome this explosion, and I think you will agree that there are a number of good reasons for it.

One reason is more people, especially more young people, are engaging in physical activity. Another is more leisure, and more affluence.

A third reason I suspect is the desire to escape from the more mechanised and prepackaged aspects of our society. More of us feel the need to express our own physical personality through participation in sport.

All these factors, I submit, have generated a quantitative explosion. But there is a qualitative upsurge too. Competition is increasing. Standards are improving greatly.

To some extent, this improvement in standards is a product of better facilities - of more sophisticated training methods, of scientific coaching and very much better equipment. Pole vaulting is just one example: Between 1942 and 1960 the world record was broken only twice, and in that time the height cleared was raised by only $1 \frac{1}{2}{ }^{\prime \prime}$. Since 1961, however, when the fibre-glass pole was introduced, the record has been broken many times and has been raised by over 2 feet. The development of the tartan track has also had a considerable effect on runners and hurdlers. It was on the tartan surface at Crystal Palace, for instance that David Hemery broke the 110 yards hurdles record in May 1969.

These are great achievements. But it is a question I hope you will discuss, as to how far we should go in providing what some may call artificial aids to record-breaking. I am not thinking here of the arguments over running shoes or steak for oarsmen. More important is the question of how far it should be permissible - if indeed it is permissible at all - to use dietary or chemical stimulants to improve performance.

To what extent, if at all is the use of amphetamines safe?

No doubt you will be considering these and related questions. But allow me to express my personal view that in individual contests, the victory nearly always will go to that sportsman who in the end is mentally, not just physically, prepared to drive himself the hardest - to stretch his limbs beyond endurance; to produce that last extra gasp; to give more than he has, or more than he thinks that he has, in order to reach the tape first.

On this subject, I quote the works of Dr. Roger Bannister. He wrote in Volume Two of "Structure and Function of Muscle" (1960): "The difference between athletes lies not entirely in difference of cardiac output or diffusion capacity; it lies, rather, in their capacity for mental excitement, which brings with it an ability to overcome or ignore the discomfort, even pain, in the muscles and in the brain, which is probably caused by ischaemia and the consequent changes of blood lactate concentration and pH." So, as Bannister puts it, "physiology may well indicate respiratory and circulatory limits to muscular exercise, but it is psychological and other factors, beyond the ken of physiology, that set the razor's edge of defeat or victory, and determine how closely an athlete approaches the absolute limits of performance".

No doubt you will be discussing this question in some detail. I feel sure that it will bring you up against the question of sporting injuries. Much good work already has been undertaken and more is under way. I am glad to say that the Sports Council has itself been active in helping to sponosr research. There was, for instance, the report from the Royal College of Physicians on the medical aspects of boxing (1969). The Sports Council assisted in this worthwhile project which revealed valuable new information on the extent to which boxers could now suffer brain damage as a result of their careers in the ring. 
Similarly, the Sports Council at the moment is supporting a further study by the Medical Faculty at Newcastle University, in collaboration with the Regional Hospital Board, in which for a year the number and extent of sporting injuries will be analysed. We hope to discover which agencies and forms of treatment are, in fact, used and how great the delay is in returning athletes to competition.

If I have any special plea to make about all these studies it is that the knowledge and the benefits from them should be shared as widely as possible. Many more middle aged folk are sportsmen of sorts these days, and as participation in sporting activities increases, and striving for excellence reaches out for new thresholds, so too the problem of injuries is likely to increase with it.

The international sportsman, the first-class football and athletics clubs all have the benefits of modern science and medicine at their behest. That is as it should be. But we need the benefit of this experience and expertise at every level of sporting activity, just as we need the collective wisdom of everyone engaged in sports medicine right down at grass roots level.

And that brings me to $\mathrm{my}$ second theme. As Minister with special responsibilities for sport and recreation in Britain, I am anxious to encourage not just excellence but mass participation in our sporting activities. Playing - not just watching could, and should, give satisfaction to the many, not just to the few.

So my concern is not only with the world beater; it is with the ordinary sportsman, with the weekend golfer and cricketer, with the less-than-brilliant athlete, with those who love the solitude of the woods and the mountains, with the child who enjoys games but who is unlikely to be around when the medals dre handed out.

Let us by all means cheer the champion athlete, and admire the football hero. But let that admiration be the spur which lifts the remainder of us from our armchairs onto the playing fields or into the swimming pools. The peaks are important but I am just as interested in raising the plateaux.

It is for this reason that I am so pleased at the increasing number of people around middle age, either individually or in family groups, who are taking advantage of the new sporting and recreational facilities open to them through increased leisure opportunities. I note too - and I suppose that I am now middle-aged myself - that there might be medical implications that need to be watched very carefully.

My medical advisers tell me that the relationship between sport and health is a very complex matter. It needs to be explored in a precise and detailed manner, using all the known techniques of psychology, sociology and physiology, and above all it must be done in stages.

I am in these matters a layman. But among the questions that have been raised by the development of middle aged sportmen are these:

1. Does an intermittent exercise sport, like football, cricket or rugby, really improve the fitness of the middle aged? Does it increase the maximal oxygen capacity of those over $\mathbf{4 0}$ years of age?

2. Does an improvement in fitness, as measured by maximal oxygen capacity, lead to a reduction in coronary disease?

A pointer if not the full answer to these vital questions may come from a pilot study now being undertaken of the effect of exercise on middle aged men by the Medical Research Council.

This study to which the Sports Council has offered a small contribution, recently started, and will run for a year in Mr. Al Murray's London gymnasium. Between 50 and 150 relatively unfit men between 40 and 55 are being taken through a controlled training programme.

3. Whether time spent in physical activity improves academic performance? The answer from studies in Sweden is "yes" - at least for schoolchildren. But we do not yet know the answer for other ages, and stages. Who better to find out than the World Congress?

4. Does the sportsman's decision-making process bring benefits to his character and to those subtler physiological and psychological qualities we call "moral stamina"? I have in mind, for example, the athlete's need to decide whether or not to drive his weary and painful limbs to even greater endurance, in order that he may place not necessarily first 
but possibly third or fourth, for the sake of his club or his country; or whether, he would be wiser, again in the interests of his team as well as himself, to ease the strain on his muscles, and to save himself for the next time.

Then there is the question of the man who comes back from defeat, Lachie Stewart, I think, had been written off as a long distance sprinter, he was said not to have the staying power for that final burst. But Stewart never gave up. He kept coming back from defeat, and we all saw at the Commonwealth Games in Edinburgh how he won that 10,000 metres. That was certainly courage.

There are as yet no final answers to these major questions. But perhaps again this conference will provide some. Certainly all these questions are of international interest and the number of countries represented at this Congress and the distinguished delegates we have with us bear witness to the importance in which sports medicine is held around the world.

It gives me great pleasure to declare open the 18th World Congress of Sports Medicine.

\section{OBITUARY}

\section{PROFESSOR PAUL CHAILLEY-BERT (1890-1973)}

It is with great regret that we announce the death of Paul Chailley-Bert, President d'Honneur of the International Federation of Sports Medicine.

Born in 1890 his medical studies were interrupted by the first World War in which he served with distinction, taking part in the epic defence of Verdun and gaining the Croix de Guerre and the Legion of Honour.

From the first he evinced a love of physiology and in 1924 took charge of the course of physiology as applied to physical education, founding the Institute of Physical Education at the University of Paris some three years later. Apart from a break when he held the Chair of Physiology at Nancy, he remained director of the Institute until he retired in 1963.

In 1926 Paul Chailley-Bert was one of the founders of the F.I.M.S. rising to become its President and finally its President d'Honneur. The doyen of Sports Medicine, Paul Chailley-Bert made singular contributions to its development especially in the field of physiology and later through his international activities. A figure of considerable presence, he displayed not only great charm and culture but also a Puckish sense of humour. In later years an Honorary Member of the B.A.S.M., he will be remembered by many for his delightful contributions to the World Congress of Sports Medicine in Oxford.

With his passing ends an era in Sports Medicine and he is deeply mourned by the many of both high and low estate to whom he so generously gave his friendship and council. 